\title{
GRAIN QUALITY, NUTRIENT USE EFFICIENCY, AND BIOECONOMICS OF MAIZE UNDER DIFFERENT SOWING METHODS AND NPK LEVELS
}

\author{
Abdul Rehman ${ }^{1 *}$, M. Farrukh Saleem², Muhammad Ehsan Safdar'1, Safdar Hussain ${ }^{3}$, \\ and Naeem Akhtar ${ }^{1}$
}

Finding more efficient ways to fertilize crops will reduce $\mathrm{N}$ losses and increase nutrient uptake. A field experiment was conducted at the Agronomic Research Farm, University of Agriculture, Faisalabad, Pakistan, during 2006 and repeated in 2007. The crop was planted in three different geometrical arrangements, viz. flat sowing (rows spaced $75 \mathrm{~cm}$ ), ridge sowing (ridges spaced $75 \mathrm{~cm}$ ), and strip planting (double row strips spaced $120 \mathrm{~cm}$ with $30 \mathrm{~cm}$ between rows in a strip); NPK was applied in four different combinations (0-0-0 control, 200-100-100 low dose,250-125-125 medium dose, and 300-150-150 high dose $\mathrm{kg} \mathrm{ha}^{-1}$ ). Both fertilizer use efficiency (FUE) and $\mathrm{N}$ use efficiency (NUE) were significantly lower with the high fertilizer dose (300-150-150 kg NPK ha-1) than with the low or medium doses. The highest nitrogen uptake efficiency was with the medium fertilizer dose and proved to be a good indicator of grain yield. Among planting methods, ridge plantation resulted in higher FUE, NUE, and $\mathrm{N}$ uptake efficiency. The highest grain yield, net income, and benefit cost ratio were recorded when a crop was planted on ridges with the medium fertilizer dose. Sowing methods did not significantly affect grain quality parameters. Seed oil, protein, and starch contents were the lowest in the control. Thereafter, seed oil contents continued to decrease, while seed protein and seed starch increased with each NPK fertilizer increment.

Key words: Nutrient, NPK, efficiency, economics, planting methods, maize.

$\mathrm{N}$ itrogen use efficiency (NUE) for cereal production has been estimated near 33\% worldwide (Raun and Johnson, 1999). Cereal pricing structure, fertilizer cost, and ground water contamination risk make $\mathrm{N}$ management a prime factor to consider. Understanding $\mathrm{N}$ fluxes, its uptake, and distribution in the plant is of prime importance with respect to both environmental concerns and product quality. Uptake and $\mathrm{N}$ utilization in crops are two major components of the $\mathrm{N}$ cycle. Efficiency may be measured in relation to the total available $\mathrm{N}$ (soil + fertilizer) or only to fertilizer. Because of the difficulty in measuring soil $\mathrm{N}$ and the economic importance of fertilizers, most studies deal with $\mathrm{N}$ fertilizer as in the present study.

A high $\mathrm{N}$ application rate leads to more rapid leaf area development, prolongs leaf life, improves leaf area duration after flowering, and increases overall crop assimilation, thus contributing to increased yield (Balasubramaniyan and Palaniappan, 2001). Phosphorus significantly increases the number of cobs per plot, 1000-grain weight, and grain yield over the control

${ }^{1}$ University College of Agriculture, University of Sargodha, LahoreKhushab Bypass Road, Sargodha, Pakistan.

*Corresponding author (drabdulrehman18@yahoo.com).

${ }^{2}$ University of Agriculture, Jail Road, Faisalabad, Pakistan.

${ }^{3}$ College of Agriculture, Sub Campus of University of Agriculture, Sakhi Sarwar Road, Dera Ghazi Khan, Pakistan. PO Box N 79.

Received: 1 April 2011.

Accepted: 19 August 2011.
(Qasim et al., 2001). Phosphorus affects leaf growth and senescence dynamics in maize (Zea mays L.), and its deficiency slows down the rate of leaf appearance and reduces the final leaf area located below the main ear by 18 to $27 \%$ (Colomb et al., 2000). In a K-deficient soil, crop yield is reduced and $\mathrm{N}$ and $\mathrm{P}$ response will be small (Balasubramaniyan and Palaniappan, 2001). Potassium, a primary macro nutrient, helps in the translocation of manufactured food, has a stimulating effect on growth and development (Sahai, 1991), and grain yield in maize (Davis et al., 1996).

A balanced use of NPK has a remarkable influence on maize growth and yield. Among different NPK combinations, $120-26.2-50 \mathrm{~kg}^{\mathrm{NPK}} \mathrm{ha}^{-1}$ provided the highest grain yield (1634 and $1491 \mathrm{~kg} \mathrm{~N} \mathrm{ha}^{-1}$ ) and net income (Rs. 10300 and $7980 \mathrm{ha}^{-1}$ ) for $2 \mathrm{yr}$, respectively, over other treatments (Sahoo and Panday, 1997). There was a positive and stimulating effect of $\mathrm{N} \times \mathrm{P}$ and $\mathrm{N} \times$ $\mathrm{K}$ on plant DM, root growth, $\mathrm{N}, \mathrm{P}$, and $\mathrm{K}$ concentration within the plant, and its ultimate effect on grain yield. However, the antagonistic effect of $\mathrm{P}$ on $\mathrm{N}$ was also observed due to the imbalance in the $\mathrm{N}$ and $\mathrm{P}$ ratio on plant DM, $\mathrm{N}$ concentration, and grain yield in some treatments $\left(50 \mathrm{~kg} \mathrm{~N}+150 \mathrm{~kg} \mathrm{P}_{2} \mathrm{O}_{5} \mathrm{ha}^{-1}\right.$ and $50 \mathrm{~kg} \mathrm{~N}$ $\mathrm{ha}^{-1}+200 \mathrm{~kg} \mathrm{P}_{2} \mathrm{O}_{5} \mathrm{ha}^{-1}$ ) (Tariq et al., 1999). Applying $\mathrm{N}$ increased protein content in grain and was optimum at 200 $\mathrm{kg} \mathrm{N} \mathrm{ha}^{-1}$ (Razzaq, 1990). Applying $\mathrm{K}_{2} \mathrm{O}$ at 200, 150, and $100 \mathrm{~kg} \mathrm{ha}^{-1}$ increased maize grain yield by $24.50,20.31$, 
and $13.14 \%$, respectively, over the control, while $\mathrm{K}_{2} \mathrm{O}$ at $200 \mathrm{~kg} \mathrm{ha}^{-1}$ increased grain yield, grain starch content, grain oil content, grain protein content, and net income by $24.50,3.58,0.23,0.25$, and $31.19 \%$, respectively, over the control.

Planting maize on raised bed gave a higher grain yield than other planting methods (Chatha and Shakoor, 1983). The ridge system of cultivation was better under contour tillage in maize for a higher grain yield (Rawitz et al., 1983). It is imperative that maize be planted using a versatile method that ensures the efficient uptake of nutrients and minimum mutual over shading and interplant competition along with the most appropriate fertilizer rate. Improved planting or sowing methods have the potential to increase crop yield (Bewley et al., 2006).

Keeping this in mind, the present study was planned to find better NPK combinations to enhance maize grain yield, grain protein, and/or oil contents with the hypothesis that the efficiency of applied nutrients/fertilizer varies with different planting methods.

\section{MATERIALS AND METHODS}

The experiment was conducted at the Agronomic Research Farm, University of Agriculture, Faisalabad $\left(31^{\circ} \mathrm{N}, 73^{\circ} \mathrm{E} ; 184.4\right.$ m.a.s.1.), Pakistan during 2006 and repeated in 2007. Physico-chemical soil properties of the experimental site are shown in Table 1. The soil was sandy clay loam. Before sowing the crop, soil samples were collected at a depth of $30 \mathrm{~cm}$ and analyzed for various physico-chemical properties. The percentage of sand, silt, and clay was determined using the Bouyoucos hydrometer method. A distilled water and 1\% sodium hexameta-phosphate solution was used for overnight soaking of $50 \mathrm{~g}$ soil samples. Dispersion was then done with an electric stirrer and transferred to a $1 \mathrm{~L}$ graduated cylinder. Silt and clay particles (\%) were determined using a Bouyoucos hydrometer; and textural class was determined with the help of an international textural triangle (Moodie et al., 1959). The $\mathrm{pH}$ of saturated soil paste, electrical conductivity (EC) of saturated soil paste, organic matter, total $\mathrm{N}, \mathrm{P}$, and extractable $\mathrm{K}$ were determined using methods and formulae from Handbook 60, Method 21a, and Handbook 60, Method 3a and 4b, respectively (Moodie et al., 1959; Jackson, 1962; Watanabe and Olsen, 1965).

Meteorological data for the experimental growth periods (2006 and 2007) were collected from the meteorological observatory of the Department of Crop

Table 1. Soil physico-chemical analysis.

\begin{tabular}{|c|c|c|c|c|c|c|c|c|c|}
\hline Year & Sand & Silt & Clay & $\mathrm{EC}$ & $\mathrm{pH}$ & OM & $\begin{array}{c}\text { Total } \\
\mathrm{N}\end{array}$ & $\begin{array}{c}\text { Available } \\
\text { P }\end{array}$ & $\begin{array}{c}\text { Available } \\
\text { K }\end{array}$ \\
\hline & - & $\%$ & - & $\mathrm{dS} \mathrm{m}^{-1}$ & & 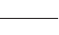 & & $-\mathrm{p}$ & $\mathrm{ppm}-$ \\
\hline 2006 & 65 & 15 & 20 & 1.67 & 8.2 & 0.72 & 0.050 & 5.18 & 170 \\
\hline 2007 & 62 & 17 & 21 & 1.68 & 8.2 & 0.73 & 0.051 & 5.44 & 172 \\
\hline
\end{tabular}

EC: electrical conductivity; OM: organic matter.
Physiology, University of Agriculture, Faisalabad, Pakistan (Figures 1 and 2). The crop was planted in three different geometrical arrangements, viz., flat sowing (rows spaced $75 \mathrm{~cm}$ ), ridge sowing (ridges spaced $75 \mathrm{~cm}$ ), and strip planting (double row strips spaced $120 \mathrm{~cm}$ with $30 \mathrm{~cm}$ between rows in a strip); NPK was applied in four different combinations (0-0-0, 200-100-100, 250-125125, and 300-150-150 kg NPK ha-1). The experiment was laid out in a randomized complete block design (RCBD) with a factorial arrangement of three replicates. The plot size was $3 \mathrm{~m} \times 7 \mathrm{~m}$, and four lines were maintained in each plot. Sowing was done by the dibbling method placing two seeds manually per hill $20 \mathrm{~cm}$ apart. Nitrogen fertilizer was applied in the form of urea: 1/3 dose at sowing, 1/3 at 60 $\mathrm{cm}$ height, and the remaining $1 / 3$ at tasseling. Phosphorus fertilizer was applied as diammonium phosphate (DAP) as the basal dose. Potassium fertilizer was applied as muriate of potash as the basal dose. Ten irrigations were applied in addition to rainfall during the crop's growing period. The first irrigation was applied $20 \mathrm{~d}$ after sowing, while subsequent irrigations were applied when needed. All irrigations, consisting of $7.5 \mathrm{~cm}$ (excluding pre-sowing), were applied to the crop each year. The crop was thinned when it attained a $15 \mathrm{~cm}$ height to maintain one plant per hill. The crop was kept free of weeds by hoeing twice to avoid weed-crop competition. All other agronomic practices were normal and uniform for all the treatments. The crop was harvested manually on 16 and 21 June 2006 and 2007, respectively.

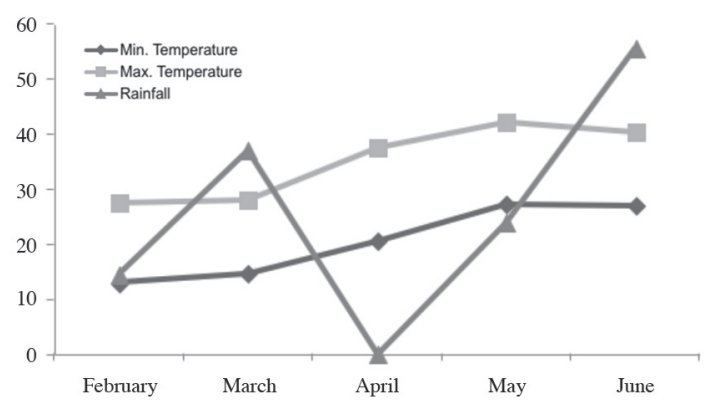

Figure 1. Temperature $\left({ }^{\circ} \mathrm{C}\right)$ and rainfall $(\mathrm{mm})$ data for the 2006 maize crop growing season.

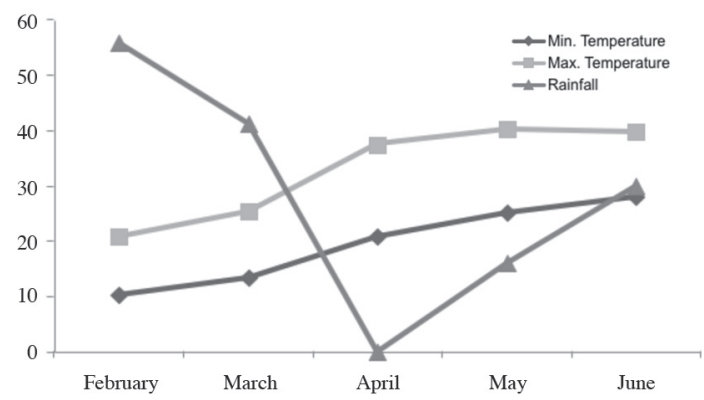

Figure 2. Temperature $\left({ }^{\circ} \mathrm{C}\right)$ and rainfall $(\mathrm{mm})$ data for the 2007 maize crop growing season. 
Agronomic fertilizer use efficiency (FUE) is defined as the increase in yield of the harvested portion of the crop per unit of fertilizer applied (Barber, 1976). It is also referred to as grain to nutrient ratio and was determined by using the following formula:

$$
\mathrm{FUE}=\frac{\begin{array}{c}
\text { Yield of fertilized plot }(\mathrm{kg})-\text { Yield of unfertilized } \\
\text { plot }(\mathrm{kg})
\end{array}}{\text { Amount of fertilizer applied }(\mathrm{kg})}
$$

Nitrogen use efficiency (NUE) and its components were determined by the formulae:

$$
\mathrm{NUE}=\mathrm{G}_{\mathrm{w}} / \mathrm{N}_{\mathrm{s}}
$$

Uptake efficiency $=\mathrm{N}_{\mathrm{t}} / \mathrm{N}_{\mathrm{s}}$

Utilization efficiency $=\mathrm{G}_{\mathrm{w}} / \mathrm{N}_{\mathrm{t}}$

where $\mathrm{G}_{\mathrm{w}}=$ grain weight, $\mathrm{N}_{\mathrm{s}}=\mathrm{N}$ supplied, and $\mathrm{N}_{\mathrm{t}}=$ total $\mathrm{N}$ in plant at maturity.

Experimental data for both years were economically analyzed by the methodology described in CIMMYT (1988). The purpose of this analysis was to estimate the economic returns of each productivity level. The contribution of each individual treatment towards the gross income of the crop was determined. For this purpose, the cost of maize production during 2006 and 2007 was calculated for factors such as tillage, seedbed preparation, sowing, irrigation, watch and ward, land rent, harvesting, and threshing that were kept uniform in both experiments. Then the variable cost incurred on the different rates of urea, DAP, and muriate of potash in each treatment was calculated separately. Therefore, gross income was computed on the basis of maize yield per hectare according to the present market value. Subsequently, the benefit cost ratio (BCR) for all the individual treatments was calculated by the following formula:

$$
\mathrm{BCR}=\text { Gross income/Total cost }
$$

Net income (Rs. ha ${ }^{-1}$ [86.39 Rs. $=1.00$ US dollar]) was also calculated by subtracting the total variable cost (Rs. ha ${ }^{-1}$ ) from the gross income (Rs. ha $\left.{ }^{-1}\right)$ for each individual treatment. Seed oil contents were determined by the Soxhlet Fat Extraction method (AOAC, 1984). The Micro-Kjeldhal method (Anonymous, 1990) was employed to determine $\mathrm{N}$ contents and then the crude protein content was calculated by multiplying $\mathrm{N}$ content with 6.25. Grain starch content (\%) was determined by the gluco-amylase method (Anonymous, 1990).

Data collected in both years were statistically analyzed with the 'MSTAT' statistical package (Anonymous, 1986). Fisher's ANDEVA technique and the differences among the treatment means were compared by employing LSD at 5\% probability (Steel et al., 1997). Graphs were prepared with the EXCEL graphics computer package.

\section{RESULTS}

\begin{tabular}{|c|c|c|c|c|c|}
\hline \multirow{2}{*}{$\begin{array}{l}\text { Sowing } \\
\text { method }\end{array}$} & \multirow[b]{2}{*}{ N-P-K rate } & \multicolumn{2}{|c|}{$\begin{array}{c}\text { Fertilizer (NPK) } \\
\text { use efficiency }\end{array}$} & \multicolumn{2}{|c|}{$\mathrm{N}$ use efficienc } \\
\hline & & 2006 & 2007 & 2006 & 2007 \\
\hline \multicolumn{6}{|c|}{$\mathrm{kg} \mathrm{ha}^{-1}$} \\
\hline \multirow[t]{4}{*}{ Flat } & $0-0-0$ & - & - & - & - \\
\hline & $200-100-100$ & $10.6 \mathrm{~b}$ & $13.8 \mathrm{a}$ & $33.0 \mathrm{a}$ & $36.5 \mathrm{a}$ \\
\hline & $250-125-125$ & $13.0 \mathrm{a}$ & $14.1 \mathrm{a}$ & $35.4 \mathrm{a}$ & $37.4 \mathrm{a}$ \\
\hline & $300-150-150$ & $9.8 \mathrm{c}$ & $11.2 \mathrm{~b}$ & $27.4 \mathrm{c}$ & $30.1 b$ \\
\hline \multirow[t]{4}{*}{ Ridge } & $0-0-0$ & - & - & - & - \\
\hline & $200-100-100$ & $14.4 \mathrm{a}$ & $15.4 \mathrm{a}$ & $43.2 \mathrm{a}$ & $45.7 \mathrm{a}$ \\
\hline & $250-125-125$ & $14.3 \mathrm{a}$ & $15.2 \mathrm{a}$ & $40.1 \mathrm{a}$ & $42.2 \mathrm{a}$ \\
\hline & $300-150-150$ & $9.7 \mathrm{~b}$ & $11.4 \mathrm{~b}$ & $28.9 \mathrm{~b}$ & $32.7 \mathrm{~b}$ \\
\hline \multirow[t]{4}{*}{ Bed } & $0-0-0$ & - & - & - & - \\
\hline & $200-100-100$ & $9.1 \mathrm{~b}$ & $12.1 \mathrm{~b}$ & $31.6 a$ & $34.8 \mathrm{a}$ \\
\hline & $250-125-125$ & $10.2 \mathrm{a}$ & $13.2 \mathrm{a}$ & $31.0 \mathrm{a}$ & $34.6 \mathrm{a}$ \\
\hline & $300-150-150$ & $7.9 \mathrm{c}$ & $10.5 \mathrm{c}$ & $24.7 \mathrm{~b}$ & $27.9 \mathrm{~b}$ \\
\hline \multicolumn{2}{|c|}{ LSD, $5 \%$} & 0.67 & 0.91 & 3.20 & 4.1 \\
\hline \multicolumn{2}{|c|}{ Year mean } & $11.0 \mathrm{~b}$ & $12.5 \mathrm{a}$ & $32.8 \mathrm{~b}$ & $36.0 \mathrm{a}$ \\
\hline \multicolumn{2}{|c|}{ LSD, $5 \%$} & 0.13 & & 0.38 & \\
\hline
\end{tabular}

Different NPK combinations and sowing techniques significantly affected FUE. The interaction between NPK rates and the sowing method was also significant. Table 2
Table 2. Efficiency of applied nutrients in maize under different sowing methods.

Means with distinct letters differ $(\mathrm{P}<0.05 ; \mathrm{LSD})$.

LSD: least significant difference.

indicates that during 2006, the efficiency of the applied fertilizer was higher with the 250-125-125 $\mathrm{kg} \mathrm{ha}^{-1}$ NPK rate when the maize crop was planted flat or in strips. With ridge plantation, FUE was the highest with the 200-100$100 \mathrm{~kg} \mathrm{ha}^{-1}$ NPK rate; however, it was equal to the 250 $125-125 \mathrm{~kg} \mathrm{ha}^{-1} \mathrm{NPK}$ rate. A similar trend was observed during 2007. The lowest FUE was observed with the 300$150-150 \mathrm{~kg} \mathrm{ha}^{-1}$ NPK application rate in all the sowing methods. The interactive effect of sowing methods and different NPK application rates was significant on NUE during both years of the study. With the flat-sown crop, the highest NUE was observed with the 250-125-125 kg $\mathrm{ha}^{-1}$ NPK application rate. With ridge or strip plantation, the highest NUE was with the 200-100-100 $\mathrm{kg} \mathrm{ha}^{-1}$ NPK application rate. However, both NPK application rates (250-125-125 and 200-100-100 $\mathrm{kg} \mathrm{ha}^{-1}$ ) were equal with either sowing method. The high NPK application rate (300-150-150 $\mathrm{kg} \mathrm{ha}^{-1}$ ) led to the lowest NUE in all the sowing methods. Both FUE and NUE were significantly $(\geq 0.05)$ higher during 2007 than in 2006.

By comparing the three sowing methods, ridge plantation resulted with the maximum FUE and NUE during both years (Figure 3 and 4). Nitrogen uptake efficiency (NUEup) was the highest when the maize crop was sown flat or in strips and NPK was applied at 250-125-125 kg ha-1. With ridge sowing, NUEup was also the highest when NPK was applied at 250-125-125 $\mathrm{kg} \mathrm{ha}^{-1}$; however, it was equal to the 200-100-100 $\mathrm{kg} \mathrm{ha}^{-1} \mathrm{NPK}$ application rate. Nitrogen utilization efficiency (NUEuti) was significantly higher with the 200-100-100 $\mathrm{kg} \mathrm{ha}^{-1}$ NPK application rate than with other rates, irrespective of sowing methods and year of study. Year analysis indicated that NUEup was significantly higher $(0.51 \%)$ during 2007 than in $2006(0.42 \%)$, while NUEuti was significantly higher (78.4\%) during 2006 than in 2007 (71.1\%) (Table 3).

Table 4 shows that sowing methods did not significantly 


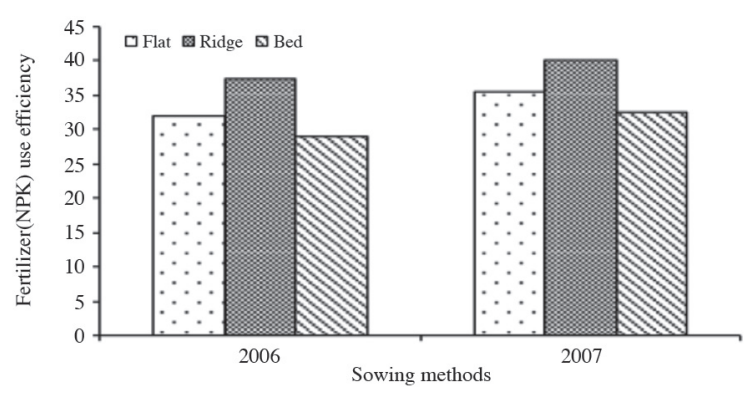

Figure 3. Effect of different sowing methods on fertilizer use efficiency in spring maize during 2006 and 2007.

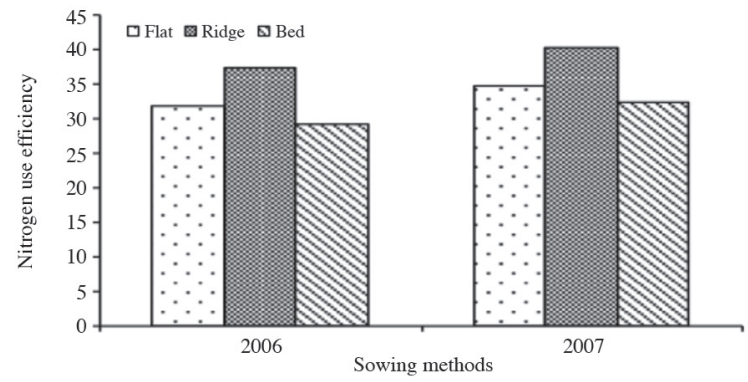

Figure 4. Effect of different sowing methods on nitrogen use efficiency in spring maize during 2006 and 2007.

Table 3. Effect of different sowing methods and NPK rates on nitrogen use efficiency components.

\begin{tabular}{|c|c|c|c|c|c|}
\hline \multirow{2}{*}{$\begin{array}{l}\text { Sowing } \\
\text { method }\end{array}$} & \multirow[b]{2}{*}{ N-P-K rate } & \multicolumn{2}{|c|}{$\begin{array}{l}\text { N uptake } \\
\text { efficiency }\end{array}$} & \multicolumn{2}{|c|}{$\begin{array}{l}\text { N utilization } \\
\text { efficiency }\end{array}$} \\
\hline & & 2006 & 2007 & 2006 & 2007 \\
\hline & $\mathrm{kg} \mathrm{ha}^{-1}$ & & & & \\
\hline \multirow{4}{*}{ Flat } & $0-0-0$ & - & - & - & - \\
\hline & $200-100-100$ & $0.38 \mathrm{~b}$ & $0.46 \mathrm{~b}$ & $87.7 \mathrm{a}$ & $79.4 \mathrm{a}$ \\
\hline & $250-125-125$ & $0.47 \mathrm{a}$ & $0.56 \mathrm{a}$ & $74.6 \mathrm{c}$ & $67.1 \mathrm{c}$ \\
\hline & $300-150-150$ & $0.34 \mathrm{~b}$ & $0.41 \mathrm{~b}$ & $80.6 \mathrm{~b}$ & $73.5 \mathrm{~b}$ \\
\hline \multirow[t]{4}{*}{ Ridge } & $0-0-0$ & - & - & - & - \\
\hline & $200-100-100$ & $0.54 \mathrm{a}$ & $0.60 \mathrm{a}$ & $80.6 \mathrm{a}$ & $75.8 \mathrm{a}$ \\
\hline & $250-125-125$ & $0.57 \mathrm{a}$ & $0.65 \mathrm{a}$ & $69.9 \mathrm{c}$ & $64.9 \mathrm{c}$ \\
\hline & $300-150-150$ & $0.38 \mathrm{~b}$ & $0.47 \mathrm{~b}$ & $76.9 \mathrm{~b}$ & $69.4 \mathrm{~b}$ \\
\hline \multirow[t]{4}{*}{ Bed } & $0-0-0$ & - & - & - & - \\
\hline & $200-100-100$ & $0.37 \mathrm{~b}$ & $0.46 \mathrm{~b}$ & $85.5 \mathrm{a}$ & $75.8 \mathrm{a}$ \\
\hline & $250-125-125$ & $0.43 \mathrm{a}$ & $0.53 \mathrm{a}$ & $72.5 \mathrm{c}$ & $65.8 \mathrm{c}$ \\
\hline & $300-150-150$ & $0.32 b$ & $0.41 \mathrm{~b}$ & $77.5 b$ & $68.5 \mathrm{~b}$ \\
\hline LSD, $5 \%$ & & 0.06 & 0.06 & 3.21 & 2.41 \\
\hline Year mean & & $0.42 b$ & $0.51 \mathrm{a}$ & $78.4 \mathrm{a}$ & $71.1 \mathrm{~b}$ \\
\hline $\mathrm{LSD}, 5 \%$ & & 0.060 & & 3.60 & \\
\hline
\end{tabular}

Any two means with distinct letters differ $(\mathrm{P}<0.05$; LSD).

LSD: least significant difference.

affect seed protein, starch, or oil contents, but all these quality parameters were affected by NPK application rates. The lowest seed protein, starch, and oil percentages were recorded with the control (no NPK applied). Seed oil content decreased at the same time as seed protein and starch content tended to increase with each increase in the NPK rate, and these differences were significant in most cases. There was no significant effect of years on seed oil content; however, seed protein and starch increased significantly more during 2007 than in 2006.
Table 4. Effect of different sowing methods on maize grain quality.

\begin{tabular}{|c|c|c|c|c|c|c|}
\hline \multirow[b]{2}{*}{ Treatments } & \multicolumn{2}{|c|}{ Seed protein } & \multicolumn{2}{|c|}{ Seed starch } & \multicolumn{2}{|c|}{ Seed oil } \\
\hline & 2006 & 2007 & 2006 & 2007 & 2006 & 2007 \\
\hline & & & & & & \\
\hline \multicolumn{7}{|l|}{ N-P-K rate, $\mathrm{kg} \mathrm{ha}^{-1}$} \\
\hline $0-0-0\left(\mathrm{~F}_{0}\right)$ & $6.72 \mathrm{c}$ & $6.87 \mathrm{~d}$ & $69.68 \mathrm{~d}$ & $70.11 \mathrm{~d}$ & $4.03 \mathrm{~d}$ & $4.07 \mathrm{~d}$ \\
\hline $200-100-100\left(\mathrm{~F}_{1}\right)$ & $7.32 b$ & $7.76 \mathrm{c}$ & $70.16 \mathrm{c}$ & $70.61 \mathrm{c}$ & $4.72 \mathrm{a}$ & $4.94 a$ \\
\hline $250-125-125\left(\mathrm{~F}_{2}\right)$ & $8.51 \mathrm{a}$ & $8.49 b$ & $70.59 b$ & $71.01 \mathrm{~b}$ & $4.68 \mathrm{~b}$ & $4.79 b$ \\
\hline $300-150-150\left(\mathrm{~F}_{3}\right)$ & $8.54 a$ & $9.09 \mathrm{a}$ & $71.91 \mathrm{a}$ & $72.34 \mathrm{a}$ & $4.57 \mathrm{c}$ & $4.62 c$ \\
\hline $\operatorname{LSD}(5 \%)$ & 0.135 & 0.164 & 0.112 & 0.124 & 0.064 & 0.076 \\
\hline \multicolumn{7}{|l|}{ Sowing method } \\
\hline Flat & 7.78 & 8.09 & 70.55 & 70.99 & 4.49 & 4.61 \\
\hline Ridge & 7.81 & 8.18 & 70.57 & 71.01 & 4.52 & 4.61 \\
\hline Bed & 7.74 & 8.11 & 70.64 & 71.06 & 4.49 & 4.60 \\
\hline $\operatorname{LSD}(5 \%)$ & NS & NS & NS & NS & NS & NS \\
\hline Year mean & $7.77 b$ & $8.05 \mathrm{a}$ & $70.59 b$ & $71.02 \mathrm{a}$ & 4.50 & 4.61 \\
\hline $\operatorname{LSD}(5 \%)$ & 0.152 & & 0.204 & & NS & \\
\hline Interaction & NS & NS & NS & NS & NS & NS \\
\hline
\end{tabular}

Any two means with distinct letters differ $(\mathrm{P}<0.05 ;$ LSD)

LSD: least significant difference; NS: non significant.

With flat and strip plantation, all NPK rates differed significantly from each other with respect to grain yield during 2006; the highest grain yield was with 250-125$125 \mathrm{~kg} \mathrm{NPK} \mathrm{ha}^{-1}$ and the lowest in the control (no NPK applied). With ridge plantation, the trend was similar, but the 200-100-100 and 300-150-150 $\mathrm{kg} \mathrm{ha}^{-1}$ NPK rates were equal with respect to grain yield. A similar trend was observed during 2007; however, grain yield was equal when NPK was applied at $250-125-125$ or 300-150$150 \mathrm{~kg} \mathrm{ha}^{-1}$ with flat and strip sowing. Grain yield was significantly higher during 2007 than in 2006 (Table 5). Calculated net income and benefit cost ratio (BCR) were the highest with the $250-125-125 \mathrm{~kg} \mathrm{ha}^{-1} \mathrm{NPK}$ application rate. When different sowing methods were compared, the ridge plantation method out yielded the others (Figure 5). Table 6 shows the correlation analyses of NUE and its component combinations along with grain yield. It is clear that all the relationships were poor except for NUEuti vs. grain yield $\left(r^{2}=0.798\right.$ and 0.668 during 2006 and 2007, respectively) and NUEup vs. NUE (0.877 and 0.789

Table 5. Effect of different sowing methods and NPK rates on maize grain yield, net income, and benefit-cost ratio (BCR).

\begin{tabular}{|c|c|c|c|c|c|}
\hline \multirow{2}{*}{$\begin{array}{l}\text { Sowing } \\
\text { method }\end{array}$} & \multirow[b]{2}{*}{ N-P-K rate } & \multicolumn{2}{|c|}{ Grain yield } & \multirow{2}{*}{$\frac{\text { Net income }}{2-y r \text { mean }}$} & \multirow{2}{*}{$\frac{\text { BCR }}{\text { 2-yr mean }}$} \\
\hline & & 2006 & 2007 & & \\
\hline & $\mathrm{kg} \mathrm{ha}^{-1}$ & \multicolumn{2}{|c|}{$\mathrm{t} \mathrm{ha}^{-1}$} & Rs. & Rs. \\
\hline \multirow[t]{4}{*}{ Flat } & $0-0-0$ & $2.35 \mathrm{~d}$ & $2.29 \mathrm{c}$ & 10165.5 & 1.54 \\
\hline & $200-100-100$ & $6.60 \mathrm{c}$ & $7.29 b$ & 57440.0 & 2.77 \\
\hline & $250-125-125$ & $8.85 \mathrm{a}$ & $9.34 \mathrm{a}$ & 77811.9 & 3.17 \\
\hline & $300-150-150$ & $8.21 \mathrm{~b}$ & $9.02 \mathrm{a}$ & 68395.4 & 2.74 \\
\hline \multirow[t]{4}{*}{ Ridge } & $0-0-0$ & $2.86 \mathrm{c}$ & $2.95 \mathrm{c}$ & 17498.6 & 1.93 \\
\hline & $200-100-100$ & $8.63 b$ & $9.13 b$ & 78489.2 & 3.42 \\
\hline & $250-125-125$ & $10.02 \mathrm{a}$ & $10.54 \mathrm{a}$ & 92616.5 & 3.58 \\
\hline & $300-150-150$ & $8.68 b$ & $9.81 \mathrm{~b}$ & 76219.2 & 2.94 \\
\hline \multirow[t]{4}{*}{ Bed } & $0-0-0$ & $2.68 \mathrm{~d}$ & $2.09 \mathrm{c}$ & 11017.2 & 1.59 \\
\hline & $200-100-100$ & $6.31 \mathrm{c}$ & $6.94 b$ & 50313.9 & 2.55 \\
\hline & $250-125-125$ & $7.75 \mathrm{a}$ & $8.67 a$ & 66731.3 & 2.86 \\
\hline & $300-150-150$ & $7.41 \mathrm{~b}$ & $8.39 \mathrm{a}$ & 59439.2 & 2.51 \\
\hline $\operatorname{LSD}(5 \%)$ & & 0.27 & 0.71 & & \\
\hline Year mean & & $6.7 b$ & $7.3 \mathrm{a}$ & - & - \\
\hline $\operatorname{LSD}(5 \%)$ & & 0.36 & - & - & \\
\hline
\end{tabular}

Any two means with distinct letters differ $(\mathrm{P}<0.05$; LSD).

LSD: least significant difference; Rs.: Pakistani rupees, (86.39 Rs. $=1.00$ US Dollar). 
during 2006 and 2007, respectively). The relationship between NUEup and NUEuti was negative.

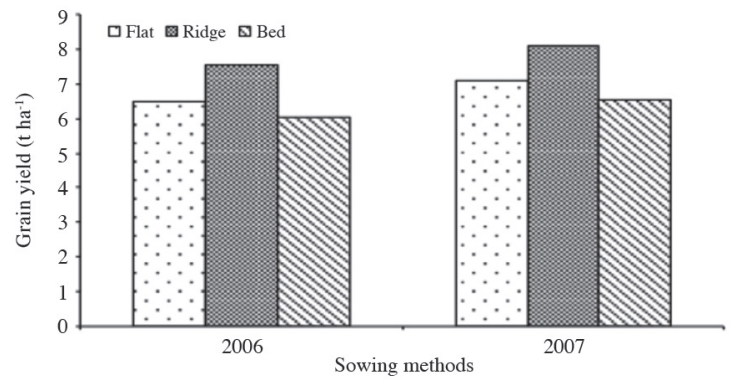

Figure 5. Effect of different sowing methods on maize grain yield during 2006 and 2007.

Table 6. Linear regression coefficient $\left(\mathbf{r}^{2}\right)$ between NUE, its component combinations, and maize grain yield.

\begin{tabular}{lcc}
\hline & \multicolumn{2}{c}{ Linear regression coefficient $\left(\mathrm{r}^{2}\right)$} \\
\cline { 2 - 3 } Characters & 2006 & 2007 \\
\hline NUE vs. Grain yield & 0.232 & 0.087 \\
NUEup vs. Grain yield & 0.489 & 0.332 \\
NUEuti vs. Grain yield & 0.798 & 0.668 \\
NUEup vs. NUE & 0.877 & 0.789 \\
NUEuti vs. NUE & 0.025 & 0.006 \\
NUEup vs. NUEuti & -0.242 & -0.143
\end{tabular}

NUE: Nitrogen use efficiency; NUEup: Nitrogen uptake efficiency; NUEuti: Nitrogen utilization efficiency.

\section{DISCUSSION}

Finding more efficient ways to fertilize crops will reduce $\mathrm{N}$ losses and increase nutrient uptake. The interaction effects of NPK application rates and sowing methods were significant on FUE, NUE, and NUE components, indicating that different NPK combinations behaved differently under different planting methods. The highest FUE (when averaged over different sowing methods) was recorded by applying 250-125-125 kg NPK ha-1, which seems to be most suitable NPK combination under the soil conditions given in Table 1. Cassman et al. (2002) reported that the highest fertilizer recovery was obtained by applying 50-15 kg NP ha-1 and 50-30 $\mathrm{kg} \mathrm{NP} \mathrm{ha}^{-1}$ under varying soil conditions, while the lowest was recorded with the higher NPK dose (300-150-150 kg NPK ha-1). This suggests that applying fertilizer in higher amounts might have resulted in more nutrient losses. Sharif et al. (1993) and Zada et al. (2000) reported that nutrient use efficiency increased with increasing fertilizer rates up to a certain level and then started to decline. This study further suggests that FUE can be improved by providing a better environment to growing roots, that is, ridge plantation rather than flat or strip plantation. It is clear from the data (Table 1) that FUE was significantly lower with the low NPK dose (200-100-100 kg ha $\left.{ }^{-1}\right)$ than with the medium NPK dose (250-125-125 kg ha-1) in the case of flat or strip planting, but these two NPK doses were equal with respect to FUE when the crop was planted on ridges.
This suggests that ridges might have caused plants utilize applied nutrients more efficiently than flat or strip planting even when nutrients were applied in lesser amounts.

NUE (when averaged over planting methods) was also the highest with ridge plantation, which indicates that this soil manipulation would have resulted in reduced/slower $\mathrm{N}$ losses (leaching), and that plant roots grow profusely to take up nutrients from a large soil volume.

In situations with a generous $\mathrm{N}$ supply, variability in the dynamics of $\mathrm{N}$ accumulation in crops for different species under different environmental conditions can be greatly reduced when crop $\mathrm{N}$ content (amount of crop $\mathrm{N}$ per unit ground area) is related to crop biomass rather than time (Greenwood et al., 1986). This suggests that with an adequate supply of soil $\mathrm{N}$, crop $\mathrm{N}$ uptake is mainly determined by the crop growth rate. However, the increase in crop $\mathrm{N}$ content with crop mass is not linear; additional $\mathrm{N}$ uptake per unit of additional biomass declines as a crop becomes larger. Nitrogen uptake of field crops is highly variable within a single year, between years, between sites, and between crops even when $\mathrm{N}$ supplies from both the soil and additional fertilizer inputs are plentiful (Gastal and Lemaire, 2002).

In the present study, low (200-100-100 kg NPK ha-1) and medium (250-125-125 $\mathrm{kg} \mathrm{NPK} \mathrm{ha}^{-1}$ ) rates performed equally well with respect to NUE; however, the high dose (300-150-150 kg NPK ha-1) decreased NUE. This indicates that NUE might be consistent with increasing the NPK dose up to a certain level. This is contrary to Pikul et al. (2005), who commented that as applied $\mathrm{N}$ decreases, NUE continues to increase. There was a better efficiency of applied nutrients (FUE and NUE) during 2007 than in 2006; this might have resulted from better plant root growth due to more rainfall during the early crop growth period during 2007 (Figures 1 and 2).

The NUE components ( $\mathrm{N}$ uptake efficiency and $\mathrm{N}$ utilization efficiency) behaved differently. Nitrogen uptake efficiency was the highest with the medium fertilizer dose (250-125-125 kg NPK ha-1) in all the sowing methods. Nitrogen utilization efficiency was the highest with the low NPK rate followed by the high NPK dose (300-150$150 \mathrm{~kg} \mathrm{NPK} \mathrm{ha}^{-1}$ ), and the lowest utilization efficiency was observed with the medium fertilizer dose (250-125-125 $\mathrm{kg} \mathrm{NPK} \mathrm{ha-1})$; these differences were significant $(\geq 0.05)$ and consistent over all the sowing methods under study. It seems that $\mathrm{N}$ utilization efficiency played a significant role in determining grain yield, while a negative and poor dependence of grain yield on $\mathrm{N}$ uptake efficiency was observed. Laffitte and Edmeades (1994) and Thiemt (2002) also found that $\mathrm{N}$ utilization efficiency played a dominating role in determining grain yield. Presterl et al. (2002) commented that a balanced combination of the two components is necessary to attain superior grain yields; however, they found a negative correlation between the two components, which was also determined in the present study. Our results contradict those of Moll et al. 
(1987) and Bertin and Gallais (2000), who reported an almost equal contribution of both components. Our study further suggests that NUEup and NUE were strongly associated, but neither of the two had any significant relationship with economic output (grain yield). NUEup and NUEuti are negatively associated because NUEup is directly related to total $\mathrm{N}$ in the plant; whereas NUEuti is inversely related with the same (refer back to formulae in materials and methods section).

Increasing NPK rates significantly increased protein contents. A higher protein value was recorded at the 300 150-150 NPK kg ha ${ }^{-1}$ rate in 2006, while the highest seed protein content was recorded at the 200-125-125 NPK kg $\mathrm{ha}^{-1}$ rate in 2007. This stimulating effect was due to the close relationship between $\mathrm{N}$ and protein. These results are in line with Javed et al. (1985) and Hejjati and Maleki (1992), who reported the stimulating effect of NPK on protein content. The stimulating effect of $\mathrm{N}$ on seed starch was reported by Hussain (1998). The same was found in this study. Seed oil content was significantly affected by different NPK rates over the control, but increasing NPK rates decreased seed oil content in both years of the study. Increasing N and/or NPK increased seed protein as well as starch (Table 4), which might have caused a reduction in seed oil content. Several researchers have demonstrated inverse relationships between seed oil and protein content (Singh et al., 1988; Zhao et al., 1993; Malik et al., 2002). Agha (1989), Khan et al. (1992), and Esechie et al. (1996) reported that grain protein, starch, and oil contents were not significantly affected by the different sowing methods. Grain yield is a function of the integrated effects of cultivar gender make-up and growing conditions on yield components of a crop. In both years, grain yield decreased at zero and at $300-150-150$ NPK $\mathrm{kg} \mathrm{ha}^{-1}$. Results confirmed that applying $250-125-125 \mathrm{~kg}$ NPK ha ${ }^{-1}$ enhances grain yield because of the increased number of cobs per plant, number of grains per cob, and 1000-grain weight (data not shown). A similar effect of fertilizer levels on maize yield and its components was reported by Samad (1992), Adediran and Banjoko (1995), and Maqsood et al. (2000).

Ridge sowing resulted in a higher grain yield than the flat and strip/bed sowing methods. This might be due to the easy penetration of maize roots in the well-pulverized soil of the ridges. Well-established roots can use nutrients more efficiently and nourish the crop well. These results are in line with those of Bhagwandin and Bhatia (1990) and Sharma and Adarmu (1991). A higher grain yield during 2007 than in 2006 resulted from better growth and yield components of the crop (data not shown) due to favorable climatic conditions during 2007 (Figures 1 and 2).

The higher net income value (Rs. $92616.46 \mathrm{ha}^{-1}$ ) and BCR (3.58) recorded in the treatment with the 250-125$125 \mathrm{~kg} \mathrm{ha}^{-1}$ NPK level and the crop sown on ridges was also due to more nutrient availability under prevailing soil environments.
The overall impact of adopting increased NUE production practices suggests that there will be less risk for the environment, but economic risks increase considerably because short-term adoption would likely be costly. Our results conclude that planting maize on ridges and applying a medium NPK dose (250-125-125 kg ha-1) was safer from both the environmental and economic point of view because applying excess nutrients will inflate production costs and possibly pollute the environment without increasing FUE and/or NUE.

\section{CONCLUSIONS}

It can be concluded that under semi-arid climatic conditions with sandy clay loam soil in the Punjab province of Pakistan, the most suitable planting method for the spring maize crop is ridge sowing with ridges spaced $75 \mathrm{~cm}$, which results in higher FUE, NUE, and N uptake efficiency. The optimum fertilizer dose is 250-125$125 \mathrm{NPK} \mathrm{kg} \mathrm{ha}^{-1}$, which not only increases grain yield $(\mathrm{t}$ $\mathrm{ha}^{-1}$ ) but also improves grain quality in terms of protein and starch contents. The combination of ridge sowing with these nutrient levels considerably enhances net income per hectare and nutrient use efficiency. It is recommended that these types of studies also be extended to other types of climates and soils in the country in order to develop a site-specific package of production technology for the maize crop.

\section{ACKNOWLEDGEMENTS}

The authors are very thankful to Dr. M. Asghar Malik, Professor (R), Department of Agronomy, University of Agriculture, Faisalabad, Pakistan, who provided the opportunity to write this article.

Calidad del grano, eficiencia de uso de nutrientes y bio-economía de maíz con diferentes métodos de siembra y niveles de NPK. Encontrando maneras más eficientes para fertilizar los cultivos se reducirán las pérdidas de $\mathrm{N}$ y aumentará la absorción de nutrientes. Un experimento de campo se llevó a cabo en la Granja de Investigación Agronómica de la Universidad de Agricultura, Faisalabad, Pakistán, durante 2006 y 2007. El cultivo fue sembrado en tres modalidades geométricas diferentes: siembra plana (filas separadas $75 \mathrm{~cm}$ ), siembra en camellones (camellones separados $75 \mathrm{~cm}$ ), y plantación en hileras (franjas de doble hilera separadas por $120 \mathrm{~cm}$ con espacio de $30 \mathrm{~cm}$ entre las hileras de una franja) y cuatro combinaciones de NPK (control 0-0-0; dosis baja 200-100-100; dosis media 250-125-125, y dosis alta 300-150-150 $\mathrm{kg} \mathrm{ha}^{-1}$ ). La eficiencia de uso de fertilizantes (FUE), así como la eficiencia del uso del $\mathrm{N}$ (NUE) fue significativamente menor con la dosis más alta de fertilizante (300-150-150) que con las dosis baja o media. Eficiencia de absorción de $\mathrm{N}$ fue mayor con la 
dosis fertilizante media y demostró ser un buen indicador del rendimiento de grano. Entre los métodos de siembra, plantación en camellones resultó en una mayor extracción de unidades foliculares, NUE, y la eficiencia de absorción de N. El mayor rendimiento de grano, la utilidad neta y la relación costo-beneficio se registraron en el cultivo sembrado en camellones con dosis media de fertilizante. Métodos de siembra no afectaron significativamente los parámetros de calidad del grano. Contenido de aceite de semillas, proteína y almidón fueron los más bajos con el control. A partir de entonces, el contenido de aceite de semilla continuó disminuyendo, mientras que la proteína y el almidón de semillas aumentaron con cada incremento de fertilizantes NPK.

Palabras clave: Nutrientes, NPK, eficiencia, economía, métodos de siembra, maíz.

\section{LITERATURE CITED}

Adediran, J.A., and V.A. Banjoko. 1995. Response of maize to nitrogen, phosphorus and potassium fertilizers in the Savanna zones of Nigeria. Communications in Soil Science and Plant Analysis 26:593-606.

Agha, M.P.S. 1989. Studies on maize productivity as affected by maize legume competition. M.Sc. Thesis. University of Agriculture, Department of Agronomy, Faisalabad, Pakistan.

Anonymous. 1986. MSTAT Micro-computer statistical program. Michigan State University of Agriculture, East Lansing, Michigan, USA.

Anonymous. 1990. Official methods of analysis of the Association of Official Analytical Chemists. $15^{\text {th }}$ ed. Vol. 11. Helrich, K. (ed.) Association of the Official Analytical Chemists Inc., Arlington, Virginia, USA.

AOAC. 1984. Official methods of analysis. Association of Official Analytical Chemists (AOAC), Washington. D.C., USA.

Balasubramaniyan, P., and S.P. Palaniappan. 2001. Principles and practices of agronomy. $185 \mathrm{p}$. Agrobios, Jodhpur, India.

Barber, S.A. 1976. Efficient fertilizer use. 114-117 p. In F.L. Patteron (ed.) Agronomic research for food. Special Publication 26. American Society of Agronomy, Madison, Wiscosin, USA.

Bertin, P., and A. Gallais. 2000. Genetic variation for nitrogen use efficiency in a set of recombinant maize inbred lines I. Agrophysiological results. Maydica 45:53-66.

Bewley, J.D., M. Black, and P. Halmer. 2006. The encyclopedia of seeds: science, technology and uses. 509 p. CABI Publishers, Cambridge, USA.

Bhagwandin, K., and K.S. Bhatia. 1990. Effect of sowing methods and mulching on the intercropping of black gram with maize under rainfed condition. Crop Research (Hisar) 3:284-286.

Cassman, K.G., A. Dobermann, and D.T. Walters. 2002. Agroecosystems, nitrogen use efficiency and nitrogen management. Ambio 31:132-140.

Chatha, M.Q., and A. Shakoor. 1983. Maize production manual. 1016 p. Pakistan Agricultural Research Centre, Islamabad, Pakistan.

CIMMYT. 1988. From agronomic data to farmer recommendation: An economics training manual. 25-33 p. International Maize and Wheat Improvement Center (CIMMYT) Economics Program, Mexico D.F.

Colomb, B., J.R. Kiniry, and P. Debacke. 2000. Effect of soil phosphorus on leaf development and senescence dynamics of field grown maize. Agronomy Journal 92:428-435.

Davis, J.G., M.E. Walker, M.B. Parker, and B. Mullinix. 1996. Long term phosphorus and potassium application to corn on Coastal Plain soils. Journal of Production Agriculture 9:88-94.
Esechie, H.A., S. Elias, V. Rodriguez, and H.S. Al-Asmi. 1996 Response of sunflower (Helianthus annuus) to planting pattern and population density in a desert climate. Journal of Agricultural Science 126:255-461.

Gastal, F., and G. Lemaire. 2002. N uptake and distribution in crops: an agronomical and ecophysiological perspective. Journal of Experimental Botany 53:789-799.

Greenwood, D.J., J.J. Neeteson, and A. Draycott. 1986. Quantitative relationship for the dependence of the growth rate of arable crops on their nitrogen content, dry weight and aerial environment. Plant and Soil 91:461-466.

Hejjati, S.M., and M. Maleki. 1992. Effect of potassium and nitrogen fertilization on lysine, methionine, and total protein contents of wheat grain (Triticum aestivum L.) Agronomy Journal 64:46-48.

Hussain, I. 1998. Effect of N and S on growth, yield and quality of hybrid maize (Zea mays L.). M.Sc. (Hons) Thesis. University of Agriculture, Department of Agronomy, Faisalabad, Pakistan.

Jackson, M.L. 1962. Soil chemical analysis. Prentice Hall, Englewood Cliffs, New Jersey, USA.

Javed, A., M.R. Sabir, and M.R Hussain. 1985. Effect of different NPK combinations on the growth, yield and quality of maize. Pakistan Journal of Scientific and Industrial Research 28(6):426427.

Khan, A., A. Aziz, M. Salim, and M. Khan. 1992. Response of two maize cultivars to management inputs. Sarhad Journal of Agriculture 9:355-358.

Laffitte, H.R., and G.O. Edmeades. 1994. Improvement for tolerance to low soil nitrogen in tropical maize. II. Grain yield, biomass production and N accumulation. Field Crops Research 39:15-25.

Malik, M.A., M.A. Cheema, and M.F. Saleem. 2002. Production efficiency of canola (Brassica napus L.) as affected by different NPK levels. Pakistan Journal of Agricultural Science 39:278-280.

Maqsood, M., R. Ali, N. Nawaz, and N. Yousaf. 2000. The effect of NPK application in different proportions on the growth and yield of spring maize. Pakistan Journal of Biological Science 3:356357.

Moll, R.H., E.J. Kamprath, and W.A. Jackson. 1987. Development of nitrogen efficient prolific hybrids of maize. Crop Science 27:181186.

Moodie, C.D., N.W. Smithand, and R.A. McGreery. 1959. Laboratory manual for soil fertility development in corn (Zea mays L.) and subsequent grain yield. Crop Science 11:368-372.

Pikul, J.L., L. Hammack, and W.E. Riedell. 2005. Corn yield, nitrogen use and corn rootworm infestation of rotations in the northern corn belt. Agronomy Journal 97:854-863.

Presterl, T., S. Groh, M. Landbeck, G. Seitz, W. Schmidt, and H.H. Geiger. 2002. Nitrogen uptake and utilization efficiency of European maize hybrids developed under conditions of low and high nitrogen input. Plant Breeding 121:480-486.

Qasim, M., H. Himayrull, and M. Subha. 2001. Effect of increasing levels of phosphorus and seed rate on the economic yield of maize. Online Journal of Biological Sciences 1:40-42.

Raun, W.R., and G.V. Johnson. 1999. Improving nitrogen use efficiency for cereal production. Agronomy Journal 91:357-363.

Rawitz, E., J. Morin, W.B. Hoogmoed, M. Zargolin, and H. Etkin. 1983. Tillage practices for soil and water conservation in the semiarid zone. Soil and Tillage Research 3:211-231.

Razzaq, A. 1990. Effect of different $\mathrm{N}$ rates on grain yield and protein contents of summer maize at constant phosphorus levels. M.Sc. (Hons). Thesis. University of Agriculture, Department of Agronomy, Faisalabad, Pakistan.

Sahai, V.N. 1991. Principles and practices of crop production. $113 \mathrm{p}$ Inter-India Publications, New Delhi, India.

Sahoo, S.C., and M.M. Panday. 1997. Fertilizer requirement of babycorn (Zea mays) in wet and winter seasons. Indian Journal of Agricultural Sciences 67:397-398.

Samad, A. 1992. Effect of different combinations of NPK on grain yield and yield components of maize varieties. Sarhad Journal of Agriculture 8:17-21.

Sharif, M., S. Hussain, S.A. Rizvi, and J.K. Khattak. 1993. Maize 
response to potassium fertilizer at Mardan. Sarhad Journal of Agriculture 9:257-261.

Sharma, T.R., and L.M. Adarmu. 1991. The effect of plant population on yield of maize. Zeitschrift fur Acker und Pflanzenbau 153:315318.

Singh, A., V. Singh, and V.S. Mehta. 1988. Effect of nitrogen and sulfur on yield and nutrients uptake by rapeseed. Indian Journal of Soil Science 36:182-184.

Steel, R.G.D., J.H. Torrie, and D.A. Dickey. 1997. Principles and procedures of statistics. A biometrical approach. $3^{\text {rd }}$ ed. 400-428 p. McGraw Hill Book, New York, USA.

Tariq, M., J.M. Nelson, and J.A. Gartner. 1999. Interactive effect of nitrogen and phosphorus on dry matter weight, root growth, nutrient concentration and grain yield of corn. Pakistan Journal of Soil Science 9:74-79.
Thiemt, E.M. 2002. Untersuchungen zur bedeutung der stickstoffeffizienz fur ertragssicherheit bei Mais. $\mathrm{PhD}$ Thesis. University of Hohenheim, Stuttgart, Germany.

Watanabe, F.R., and J.R. Olsen. 1965. Test of an ascorbic acid method for determining phosphorus in water \& sodium bicarbonate extract from soil. Soil Science Society of America Proceedings 29:677-678.

Zada, K., P. Shah, and M. Arif. 2000. Management of organic farming: effectiveness of farm yard manure (FYM) and nitrogen for maize productivity. Sarhad Journal of Agriculture 16:4614654.

Zhao, F.I., E. Evans, P.E. Billsborrow, and J.K. Syers. 1993. Influence of sulphur and nitrogen on seed yield and quality of low glucosinolate oil seed rape (Brassica napus). Journal of the Science of Food and Agriculture 63:29-37. 